\title{
OPTIMASI PRODUKSI DAN IDENTIFIKASI SENYAWA ANTIMIKROB DARI JAMUR ENDOFIT Sporothrix sp LBKURCC43 TANAMAN DAHLIA (Dahlia variabilis)
}

\author{
Paslun, Saryono, Chiristine Jose \\ Laboratorium Riset Enzim, Fermentasi dan Biomolekuler \\ Jurusan Kimia, FMIPA, Universitas Riau \\ Jln. Raya Bangkinang KM 12,5 Pekanbaru 28193 \\ Penulis korespondensi. E-mail: paslunbahar@yahoo.co.id
}

\section{ABSTRACT}

Dahlia tubers contain fungus Sporothrix $s p$ which have antimicrobial activity. The objective of this research was to determine the agitation that effect the activity of antimicrobial in malt extract broth (MEB). The result showed that agitation of $150 \mathrm{rpm}$ have the antimicrobial activity against Staphylococcus aureus with $21.0 \mathrm{~mm}$ and Escherichia colii with $12.8 \mathrm{~mm}$. The identification of function group showed the extract contained $\mathrm{O}-\mathrm{H}$, $\mathrm{C}=\mathrm{O}$ and Amide with UV and IR spectroscopy.

Key Words: Antimikrobial activity, Dahlia plant, agitation, Sporothrix sp

\section{PENDAHULUAN}

Dahlia merupakan tanaman yang berbunga indah dan banyak ditemui di seluruh Indonesia terutama daerah yang beriklim dingin. Tanaman banyak manfaatnya selain sebagai tanaman hias, menuru Didik Widyatmoko Peneliti LIPI Inulin yang terkandung dalam umbi bunga dahlia, merupakan polimer dari unit-unit fruktosa. Inulin ini merupakan salah satu komponen bahan pangan yang memiliki кandungan serat sangat tinggi.

Salah satu manfaat umbi dahlia dapat digunakan sebagai sumber senyawa bioaktif. Hasil uji fitokimia yang telah dilakukan oleh Saryono et all dalam artikelnya menunjukkan bahwa secara umum sampel mengandung metabolit sekunder flavonoid, terpenoid, dan fenol. Ekstrak metanol umbi dahlia berbunga merah menunjukkan keaktivan dalam menghambat pertumbuhan Escherichia coli, Basillus subutilis, Staphylococcus aereus, Candida utilis dan Penicillium sp.

Dan telah ditemukan adanya jamur Spongotrix $s p$ yang berwarna ungu terdapat pada umbi dahlia melalui penelitian Dina fitriyah(2012), dengan adanya penemuan ini maka akan dilanjutkan lagi penelitian tentang senyawa bioaktif anti jamur dan anti bakteri yang terkandung pada umbi dahlia dengan cara isolasi dan identifikasi. Penelitian ini juga melibatkan pengaruh agitasi terhadap fermentasi untuk menghasilkan Sporothrix $s p$. Adapun fungsi agitasi dalam fermentasi ini adalah Untuk mensuspensikan mikroorganisme dan nutrient secara merata selama kultivasi serta meningkatkan laju perpindahan panas antara permukaan kultivasi dengan permukaan dingin.

\section{METODOLOGI PENELITIAN}

\subsection{Sampel}

Sampel yang digunakan pada penelitian ini adalah jamur Sporothrix $s p$ yang telah diekstraksi dan difraksinasi dari umbi dahlia (Dahlia variabilis) berbunga merah yang sudah berumur \pm 1 tahun yang diambil dari daerah Payakumbuh, Sumatera Barat.

\subsection{Fermentasi}

Sampel dari penelitian sebelumnya diinokulasi dalam media malt extract broth (MEB) sebanyak $25 \mathrm{ml}$ selama 2 hari. Kemudian diambil $5 \mathrm{ml}$ inokulum dimasukkan dalam fermentor yang berisi $900 \mathrm{ml}$ media MEB dan difermentasi selama 20 hari dengan variasi agitasi $75,100,125$ dan $150 \mathrm{rpm}$. Setiap variasi kecepatan agitasi hasil fermentasi duji aktivitasnya dengan Candida Albicans, S.Aureus dan E.Coli. 


\subsection{Ekstraksi}

Hasil fermentasi dengan kecepatan agitasi yang yang sudah mempunyai activitas pada Candida albicans, S. Aureus dan E.Coli kemudian di ekstraksi Setelah 20 hari miselia dan media dipisahkan dengan cara dekantasi. Masing - masing dari 1 liter filtrate hasil fermentasi diekstraksi dua kali dengan etil asetat bervolume 1 liter. Ekstrak dikentalkan dengan evaporator pada suhu kamar yang sebelumnya diberi penambahan $\mathrm{Na}_{2} \mathrm{SO}_{4}$ anhidrat. Residu yang diperoleh dari evaporasi dilarutkan kembali dengan metanol, dalam perbandingan $1 \mathrm{ml}$ metanol untuk setiap $1 \mathrm{~L}$ ekstrak etil asetat. Ekstrak kasar ini dapat disimpan pada suhu $-20^{\circ} \mathrm{C}$ sebelum dipergunakan.

\subsection{Deteksi Saponin dengan KLT}

Ekstrak kasar dari miselia jamur Sporothrix sp dalam metanol dianalisis dengan Kromatografi Lapis Tipis (KLT) pada plat KLT $\mathrm{SiO}_{2}$ dan digunakan DCM: metanol 80:20 (v/v) sebagai eluen. Ekstrak diambil sebanyak $10 \mu \mathrm{L}$ kemudian ditotolkan $\pm 1 \mathrm{~cm}$ dari bawah plat KLT dengan menggunakan pipa kapiler. Selanjutnya dibiarkan beberapa saat hingga pelarutnya menguap dan dimasukkan ke dalam bejana pengembang (chamber). Setelah eluen naik sampai batas garis atas, plat dikeluarkan dan dikeringkan. Noda dideteksi dengan penyemprotan reagensia yakni larutan $0,5 \%$ metoksibenzaldehid dalam larutan metanol $/ \mathrm{H}_{2} \mathrm{SO}_{4} /$ asam asetat 90:5:5 (v/v/v) dan dikeringkan pada suhu $110^{\circ} \mathrm{C}$ selama 20 menit Pemaparan dengan sinar UV (254 nm) akan meningkatkan visualitas selain reagen tersebut digunakan juga serium sulfat.

Sebanyak $0,245 \mathrm{~g}$ sampel yang telah diimpregnasi dengan $3 \mathrm{~g}$ silika adsorp dipisahkan lebih lanjut dengan kromatografi flash berdiameter kolom 1 inch menggunakan eluen metanol: etil asetat (5:5) masing-masing sebanyak $50 \mathrm{ml}$. Fraksi yang dihasilkan selanjutnya diuapkan pelarutnya dengan suhu ruangan kemudian ditimbang beratnya. Hasil yang diperoleh diuji kemurniannya dengan HPLC. Kemudian dilanjutkan dengan penentuan gugus fungsi dengan UV dan IR.

\section{HASIL DAN PEMBAHASAN}

Satu Liter filtrate dari hasil fermentasi jamur Sporothrix $s p$ pada kecepatan agitasi 75 dan 100 rpm yang dilakukan selama 20 hari di uji aktivitasnya dengan antimikrobial. Dari hasil penelitian pada kecepatan agitasi tersebut jamur sporothrix $s p$ belum dapat menghambat pertumbuhan jamur Candida albicans, $S$. auereus dan E. coli. Hal ini disebabkan karena pada kecepatan agitasi 75 dan $100 \mathrm{rpm}$ belum dapat mendistribusikan udara dan nutrient secara optimal. Agitasi merupakan factor penentu keberhasilan proses kultivasi dimana tujuan proses tersebut adalah untuk mendispersikan udara di dalam larutan media dan menyeragamkan suhu dan konsentrasi nutrient di dalam fermentor.

Tabel 1. Aktivitas antimikrobial Ekstrak Jamur Sporothrix sp

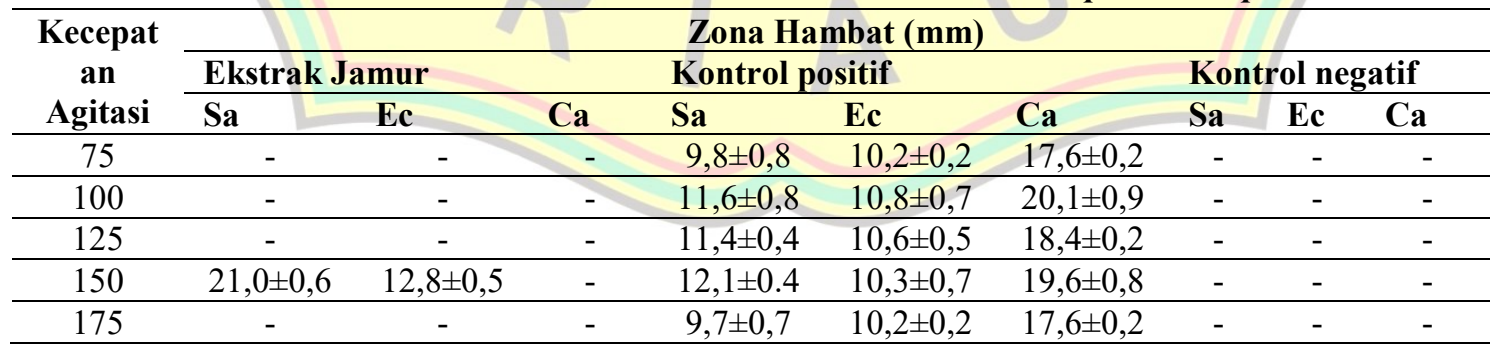




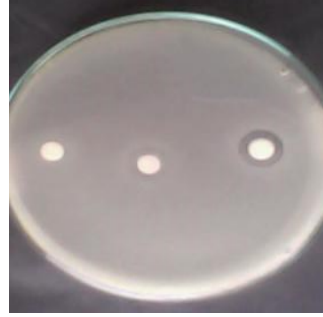

(a)

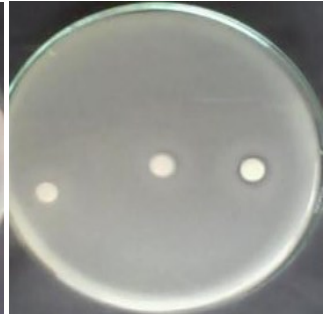

(b)

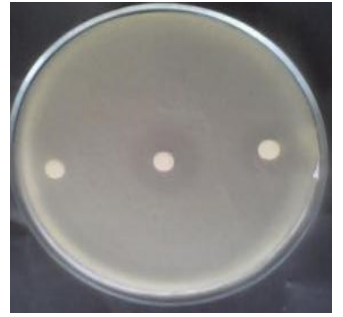

(C)

Gambar 1. Aktivitas antimikrobial jamur endofit Sporothrix sp pada bakteri patogen (a) Aspergillus aureus (b) Escherichia colli dan jamur patogen (c) Candida albicans dengan kecepatan agitasi $150 \mathrm{rpm}$.

\section{Skrining aktivitas antimikrobial jamur endofit tanaman dahlia (Dahlia variabilis)}

Diantara lima perlakuan agitasi $75,100,125,150,175$ rpm didapatkan bahwa aktivitas antimikrobial berada pada agitasi 150 rpm dengan zona hambat pada Aspergillus aureus sebesar 21,0 mm pada Escherichia colii sebesar 12,8 mm. Pada kecepatan agitasi 150 rpm merupakan kecepatan agitasi yang bisa menghasilkan aktivitas antimikrobial.

Uji antijamur terhadap Candida albicans menunjukkan bahwa ekstrak kasar jamur endofit Sporothrix sp yang di fermentasi dalam media produksi MEB pada agitasi 75,100,125 dan 175 rpm tidak menunjukkan adanya aktivitas antimikrobial.

Pada kecepatan 75,100,125rpm proses fermentasi terjadi dalam kondisi agitasi terlalu rendah sehingga berakibat tidak optimalnya proses distribusi oksigen, nutrisi dan enzim keseluruh bagian media sehingga pertumbuhan jamur tidak optimal hal ini disebabkan juga karena Sporothrix adalah mikroorganisme aerob sehingga perlakuan agitasi mendistribusikan oksigen yang dibutuhkan dalam pertumbuhan Sporothrix sp.

Pada kecepatan 175rpm, fermentasi berjalan dalam kondisi agitasi terlalu tinggi, sehingga menyebabkan proses metabolisme sel terganggu Kecepatan agitasi terlalu tinggi akan menyebabkan sebagian sel mengalami kerusakan fisik kemudian mati. Pada penelitian ini diperoleh bahwa ekstrak Sporothrix sp lebih sensitif terhadap bakteri gram positif daripada gram negatif. Diameter zona hambat yang dihasilkan oleh bakteri gram positif lebih besar dari pada gram negatif. Aktivitas zona hambat pada S.Aureus sebesar $21,0 \mathrm{~mm}$ diduga memiliki aktivitas antibakteri berkekuatan kuat karena memiliki zona hambat 10-20 mm. Hal tersebut menunjukkan bahwa bakteri gram positif tersebut lebih peka terhadap senyawa aktif yang ada pada jamur sporothrix sp.

\section{KESIMPULAN}

Dari hasil penelitian terhadap senyawa bioaktif jamur Sporothrix sp pada umbi dahlia diambil kesimpulan bahwa:

Pada fermentasi jamur endofit Sporothrix $s p$ umbi dahlia diperoleh aktivitas antimikrobial pada media MEB dengan agitasi pada $150 \mathrm{rpm}$ dengan zona hambat maksimum pada sebesar 21,0 $\mathrm{mm}$ dan pada Escherichia Colli sebesar $12,8 \mathrm{~mm}$. Hasil karakterisasi gugus fungsi dengan data UV dan IR dapat disimpulkan bahwa senyawa endofit mempunyai gugus $\mathrm{OH}, \mathrm{C}=\mathrm{O}$, Amida, dan adanya ikatan rangkap

\section{Daftar Pustaka}

Asahiko Hayashi,et al, 1995, The Journal antibiotic, vol. 49 no. 7

Fitriyah D, Penentuan Media Optimum Senyawa Anti Mikroba dari senyawa endofit tanaman Dahlia, Kimia FMIPA UNRI, 2012

Fardiaz, S, 1988, Fisiologi Fermentasi, Pusat Antar Universitas, IPB Bogor.

Saryono, Chainulfiffah, Devi, S., Monalisa, \& Dasli. 1998. Pemanfaatan Ubi Dahlia variabilis untuk Produksi Sirup Fruktosa (HFS) Dan Fruktooligosakarida (FOS). Seminar Nasional PBBMI XIV. Bandung

Strobel, G. \& Daisy, B. 2003. Bioprospecting for Microbial Endophytes and Their 
Natural Products. Microbiology and

Molecular Biology Reviews 67:491-502

Sinaga, E., Noverita, \& Fitria, D., 2003. Daya

Antibakteri Jamur Endofit yang Diisolasi dari Daun dan Rimpang Lengkuas (Alpinia Galanga SW). FMIPA Biologi. Universitas Nasional

Suciatmih. 2010. Pengaruh Konsentrasi Antimikroorganisme, Media Fermentasi, dan Waktu Inkubasi Terhadap Pertumbuhan Absidia corymbifera (Cohn) Sacc. \& Trotter dari jamur
Endofit Fusarium nivale (Fr.) Ces. Media Litbang Kesehatan Volume XX:1.

Suryadi, A.E. 2007. Ekstraksi dan Uji Aktivitas Antimikroba Ekstrak Umbi Dahlia (Dahlia variabilis). Skripsi FMIPA Universitas Riau. Pekanbaru.

Turk, F.M. 2006. Saponins versus plant fungal pathogens. Journal of Cell and Molecular Biology 5:13-17.

Yuwono, T. 2010. Biologi Molekuler. Penerbit Erlangga: Jakarta.

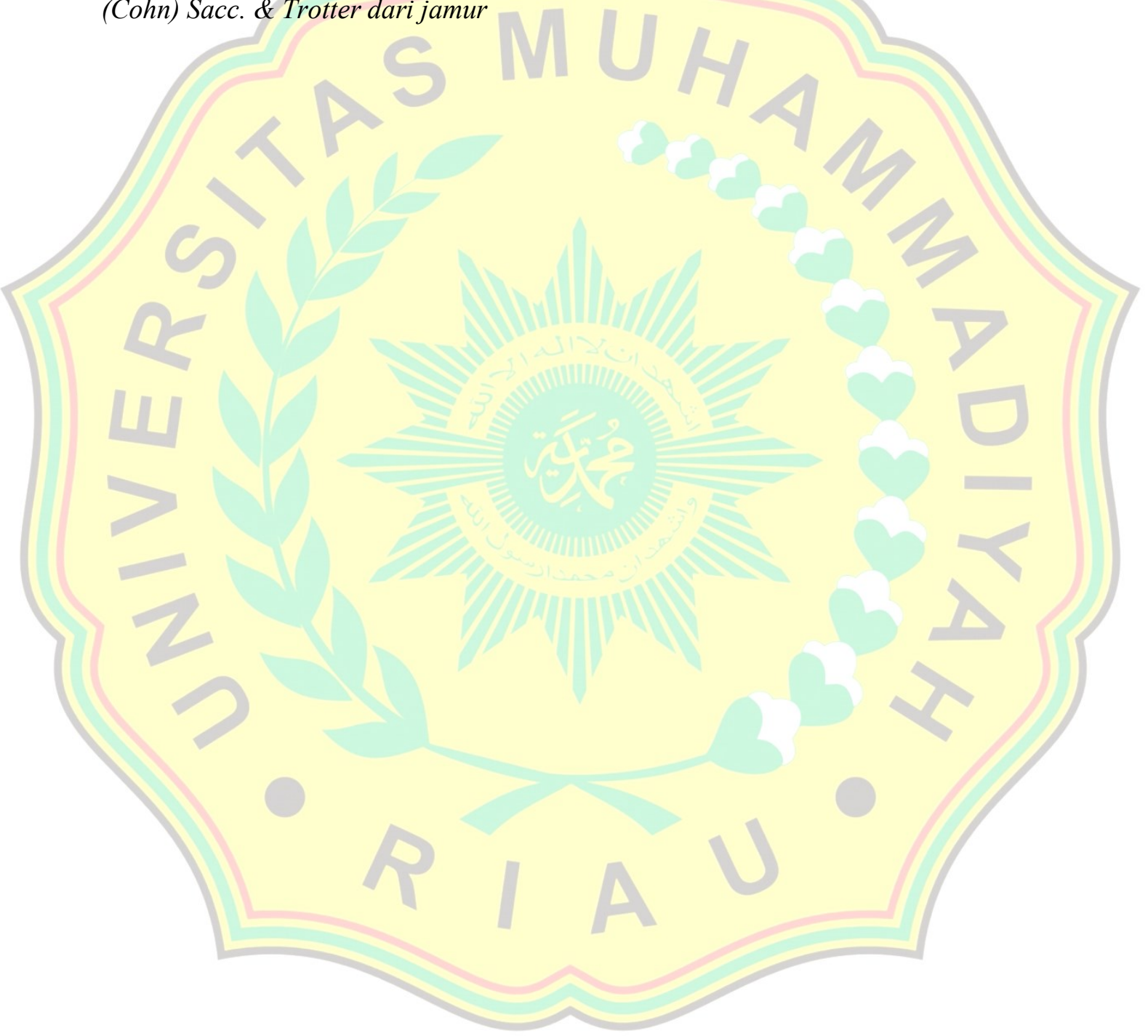

